\author{
MACIEJ SWĘD ${ }^{1 *}$, PRZEMYSŁAW NIEDZIELSKI ${ }^{2}$ \\ ${ }^{1}$ Adam Mickiewicz University in Poznań, Faculty of Geographical and Geological Sciences, Institute of Geology \\ 12 Bogumiła Krygowskiego Str., 61-680 Poznań, Poland \\ ${ }^{2}$ Adam Mickiewicz University in Poznań, Faculty of Chemistry \\ 89 b Umultowska Str., 61-614 Poznań, Poland
}

\title{
Geochemistry and mineralogy of technogenic soils developed on old mine heaps of abandoned iron ore mines in the Lawęczna area (Holy Cross Mountains, south-central Poland)
}

\begin{abstract}
The article presents the results of preliminary geochemical and mineralogical studies of technogenic soils (Technosols) of abandoned iron ore mines on the Ławęczna Hill near Miedziana Góra in the Holy Cross (Świętokrzyskie) Mountains, southcentral Poland. The results of chemical analyses (XRF) were used to calculate the soil enrichment factors of arsenic, copper, iron, lead and zinc, and compare the element concentrations to their levels in uncontaminated soils across Poland and in the city of Kielce. The highest values of soil enrichment factors of metals (As 27.699, Ni 26.455, $\mathrm{Cu} 9.353, \mathrm{Zn} \mathrm{3.344,} \mathrm{Pb} \mathrm{0.62)} \mathrm{were} \mathrm{recorded} \mathrm{for} \mathrm{the}$

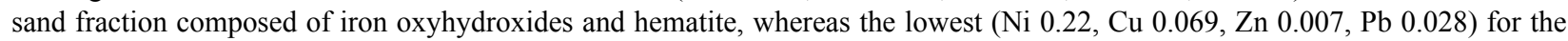
clay-silt and sand fractions, which were primarily composed of calcite and quartz as well as for gravel fraction. The clay-silt fraction shows the highest enrichment in arsenic (27.69). The examined metals and arsenic show positive geochemical anomalies.
\end{abstract}

Keywords: Geochemical background, technogenic soils, old mine heaps, geochemical anomaly

\section{INTRODUCTION}

The remains of historical ore mining in the Holy Cross Mountains, south-central Poland, include adits, anthropogenic landforms and numerous heaps, which have been of interest to geologists and in particular to mineralogists and geochemists. The accumulated ore minerals in slagheaps are essential source of information about primary mineralisation of exploited deposits, and also constitute a reservoir of elements harmful for the natural environment and humans. Soils, in which elements can be immobilized and partly excluded from geochemical cycling were the subject of mineralogical and geochemical research in the Świętokrzyskie region among others in Rudki village, Miedzianka village and Mt. Karczówka in Kielce city (Uzarowicz 2011, Dołęgowska et al. 2015, Gałuszka et al. 2014, 2016, 2018). So far, no similar geochemical characteristics have concerned technogenic soils in Miedziana Góra and its surroundings, where copper and iron deposits were extracted from Medieval times at least. The existence of this gap in the geochemical studies of the Świętokrzyskie region prompted the authors to conduct the present research.

The primary objective of this study was the geochemical and mineralogical characterisation of the clay-silt, sand and gravel fractions from surface horizons of technogenic soils developed on slagheaps of abandoned iron ore mines on Ławęczna Hill, southcentral Poland. The results allowed the authors to compare the enrichment factors of metals and arsenic in the studied soil fractions.

\section{STUDY AREA}

The research area is located within the abandoned iron ore mining field on Ławęczna Hill, located about $2 \mathrm{~km}$ west of Miedziana Góra village in the western part of the Holy Cross Mountains south-central Poland (Fig. 1). The study area is located within the Palaeozoic core of the Holy Cross Mountains, south of the primary dislocation of the entire region, in the Kielce fold zone (Konon 2008). The deposit fills the Miedziana Góra dislocation, which is parallel to the Holy Cross dislocation along which the anticline of Miedziana Góra has been pushed northwards onto the north wing of the Kostomłoty syncline (Król and Urban 2012, Rubinowski 1971, Czarnocki 1957). The Ławęczna iron deposit fills the same dislocation zone that contains the more well-known copper deposit in Miedziana Góra, the exploitation of which was limited to the eastern part of the dislocation. The copper ore deposit, which is commonly associated with pyrite, occurs within the clay-mudstone rocks, the so-called 


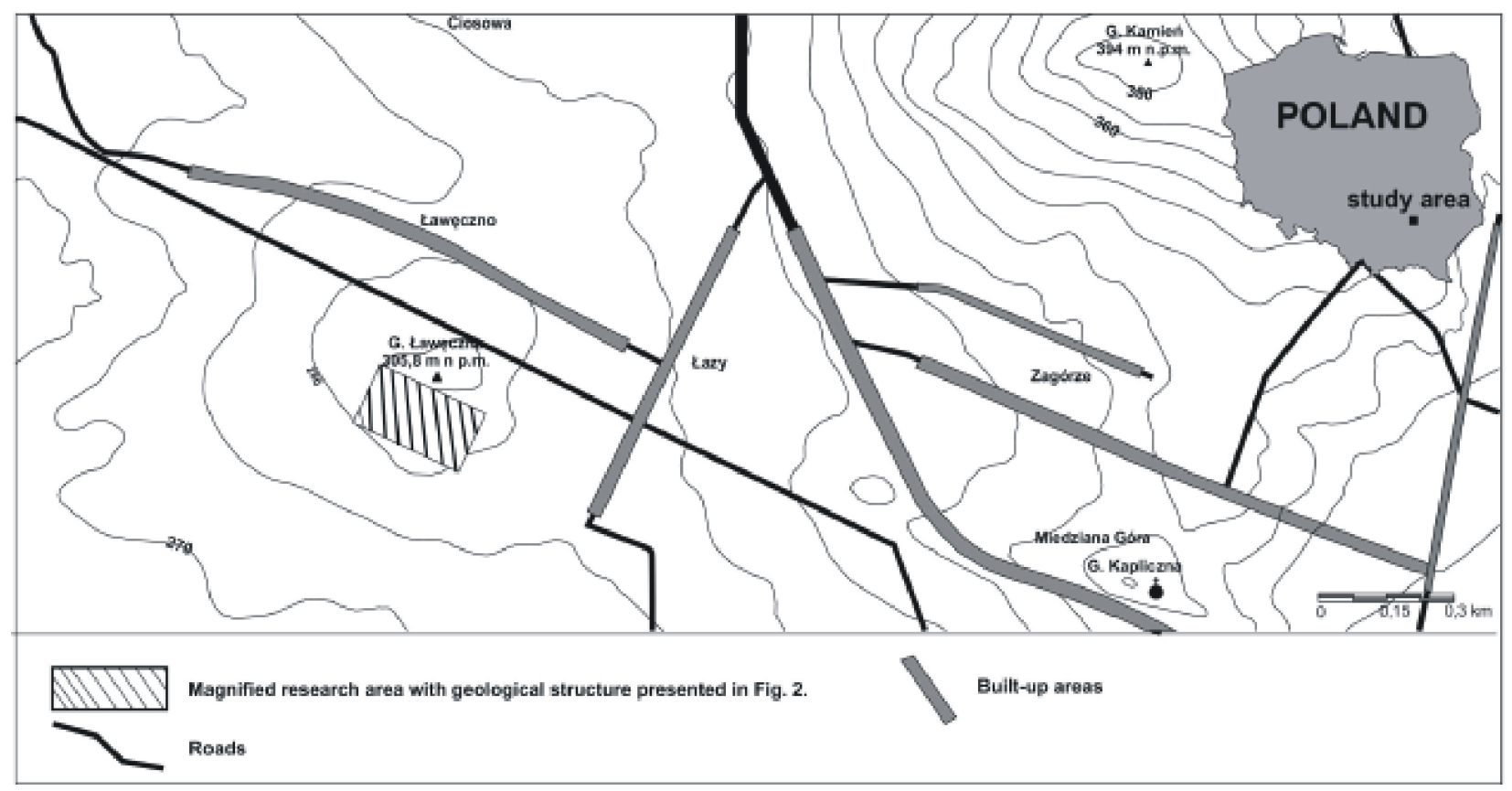

FIGURE 1. Topographic map of Miedziana Góra, Ławęczna and the study area

ore-bearing clays, in which fragments of Middle Devonian limestones and dolomites were found (Rubinowski 1971a, 1971b; Król and Urban 2012). The ore-bearing clays dip at an angle of $30-40^{\circ}$ northeast (Konstantynowicz 1971, Rubinowski 1971a, 1971b). From the north, there are the bed borders siltstones, sandstones and slightly compacted copper Lower Devonian conglomerates that build the southern wing of the Miedziana Góra anticline (Konstantynowicz 1971, Rubinowski 1971a, 1971b, Wojciechowski 2002, Król and Urban 2003, 2012).

The remains of iron ore mining are represented by numerous circular depressions, the largest of which were recorded on the southern slopes of the hill. Almost all hollows, which are a relic of sunken shafts, are surrounded by small heaps on which technogenic soils have developed. The top of the hills is built of the Miedziana Góra conglomerates and Lower Devonian sandstones, whereas the southern slopes consist of Middle Devonian limestones and dolomites (Fig. 2) (Urban 1979).

\section{MATERIALS AND METHODS}

Soil samples were collected with soil cores (LAW-I, ŁAW-II, ŁAW-III) from three sites located on the southern slopes of the Lawęczna Hill. These sites showed the highest impact of the historical iron ore mining (Fig. 1). Soil samples were taken from the surface of low slagheaps surrounding shallow circular depressions that are the remains of sunken exploitation shafts. The depth of the soil cores was from 0.2 to $0.6 \mathrm{~m}$. This shallow soil sample depth was due to the low depth of occurrence of the Lower and Middle Devonian rocks. Soil samples were collected from the following depths: $0-0.2,0.2-0.4$ and $0.4-0.6 \mathrm{~m}$ described as A, $\mathrm{B}$ and $\mathrm{C}$ respectively. The first stage of the research was $\mathrm{pH}$ measurement of soil water extracts using a Miedicaldt device, model MAT 1202-SM. The samples, dried at $40^{\circ} \mathrm{C}$, were subjected to carbonate testing according to the carbonate-bomb method. The grain size analysis and the preparation of samples for chemical analyses were started by manual washing through a mesh size $0.063 \mathrm{~mm}$ sieve using distilled water. The washed precipitate was poured into cylinders and following suspension sedimentation the samples were re-dried at $40^{\circ} \mathrm{C}$. The material remaining on the sieve was dried at $40^{\circ} \mathrm{C}$ and sieved through the following mesh sizes: $2.0,1.0,0.5,0.250,0.125$ and $0.063 \mathrm{~mm}$. The gravel $(>2 \mathrm{~mm})$ and sand fractions $(0.063-2.0 \mathrm{~mm})$ were subjected to mineralogical observations with the use of a binocular (Leica M205C model). Mineral composition of sand and silt-clay fractions was determined by using the X-ray diffraction method (XRD, Thermo Electron model, ARL X'tra). The soil samples were analysed for the content of copper, lead, zinc, nickel, titanium and arsenic. The element determinations were carried out using fluorescence X-ray apparatus (XRF, Tracer III model, Bruker USA) with a detection limit of $1 \mathrm{mg} \cdot \mathrm{kg}^{-1}$ for all elements. Both the finest clay-silt fraction $(<0.063 \mathrm{~mm})$ and the sand fraction $(0.063-2.0 \mathrm{~mm})$ as well as the gravel fraction 


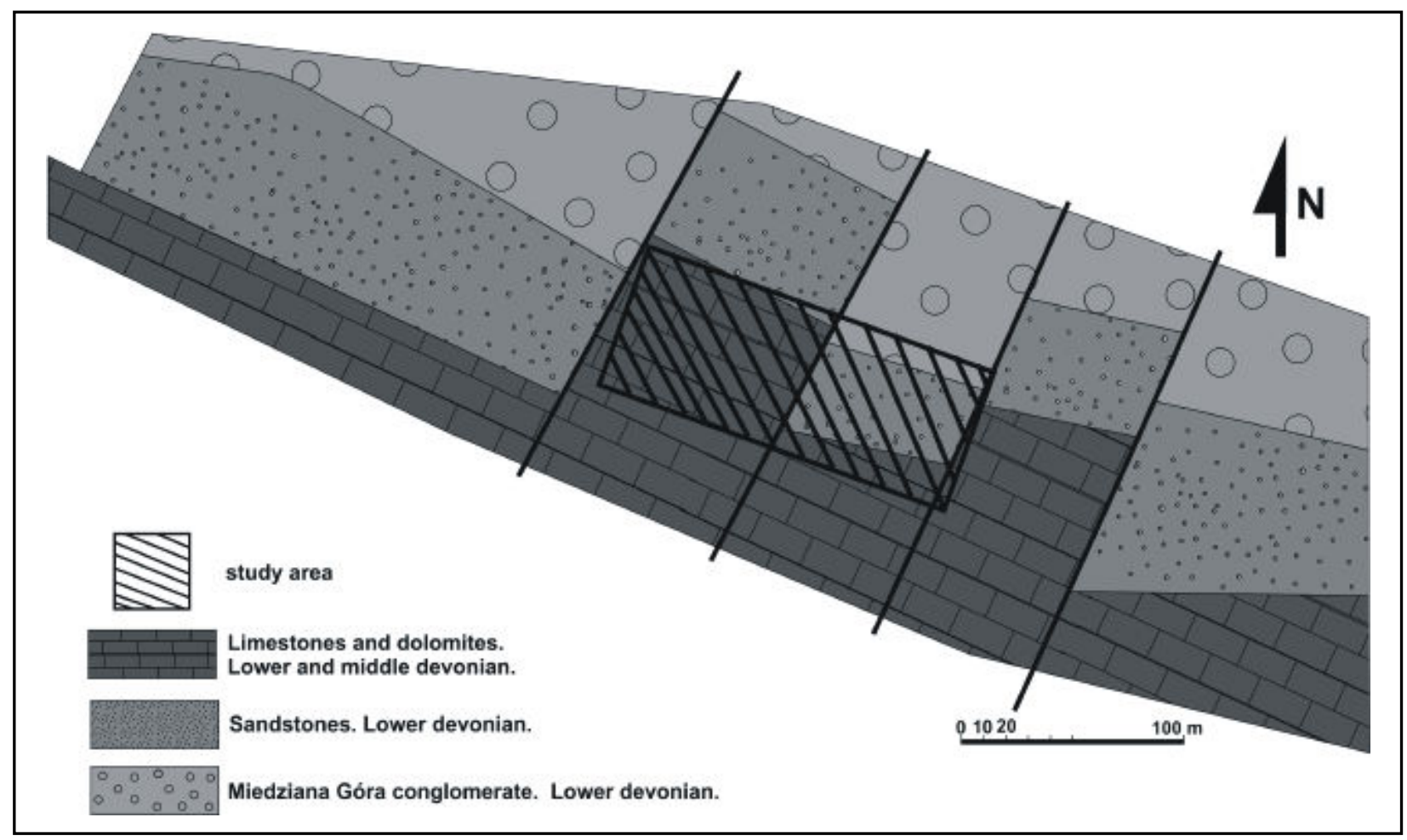

FIGURE 2. Geological structure of the study area after Urban (1978)

$(>2 \mathrm{~mm}$ ) from the first soil core underwent chemical analyses.

\section{RESULTS}

\section{Soil properties and classification}

Soil material was divided into a skeletal fraction $(\mathrm{d}>2 \mathrm{~mm})$ and fine earth $(\mathrm{d} \leq 2 \mathrm{~mm})$. In all soil samples, fine earth prevails over skeletal fraction. The sample ŁAW-II B contained almost no grains larger than $2 \mathrm{~mm}$. The most significant share of skeletal components (nearly $50 \%$ by weight) was found in the sample ŁAW-III A. Within the fine earth, silt and clay fraction $(<0.063 \mathrm{~mm})$ occurred in the highest concentration, except for the sample $Ł A W-$ II A, in which the content of fraction $<0,063 \mathrm{~mm}$ was lower than $1 \%$ by weight (Fig. 3).

The $\mathrm{pH}$ of studied samples ranged from 5.1 to nearly 8 , which allows us to classify the investigated

TABLE 1. The $\mathrm{pH}$ of the examined soil samples

\begin{tabular}{ll}
\hline Sample number & $\mathrm{pH}$ value \\
\hline LAW-I A & 7.4 \\
\hline ŁAW-I B & 7.5 \\
\hline ŁAW-I C & 7.9 \\
\hline ŁAW-II A & 5.5 \\
\hline ŁAW-II B & 5.1 \\
\hline
\end{tabular}

soils as acidic (samples ŁAW-II A, B and ŁAW-III A) and alkaline (LAW-I A, B, C) (Table 1). All soil samples contained less than $5 \%$ of carbonates.

According to the WBR soil system (IUSS Working Group WRB 2015), the studied soils can be assigned to Technosols. However, further assignment of any qualifier typical of Technosols is impossible due to the lack of detailed morphological observation of soil profiles and detailed analyses of soil properties.

\section{Mineralogical analyses}

Preliminary mineralogical observations of the soil samples using a binocular magnifying glass from all soil cores showed dominance of iron oxides in $\mathrm{EAW}-\mathrm{I}$ whereas quartz was distinguished as a main component in $Ł A W-I I$ and $Ł A W-$ III cores. The sand fraction from the $\mathrm{LAW}-\mathrm{I}$ consisted of earthy conglomerates of a rusty colour typical for iron oxides. Among the above-mentioned iron oxides, goethite was distinguished with characteristic black, botryoidal aggregates and greasy gloss, which was confirmed by the XRD analysis (Fig. 4). During mineralogical studies using a binocular magnifying glass, hematite was also found forming a red coating on iron oxides grains, clay-size crystals having black-coloured aggregates. This is distinguishable from similar-looking goethite thanks to its cherry red colour, which becomes visible on the broken edges of the mineral grains. Mineralogical ob- 

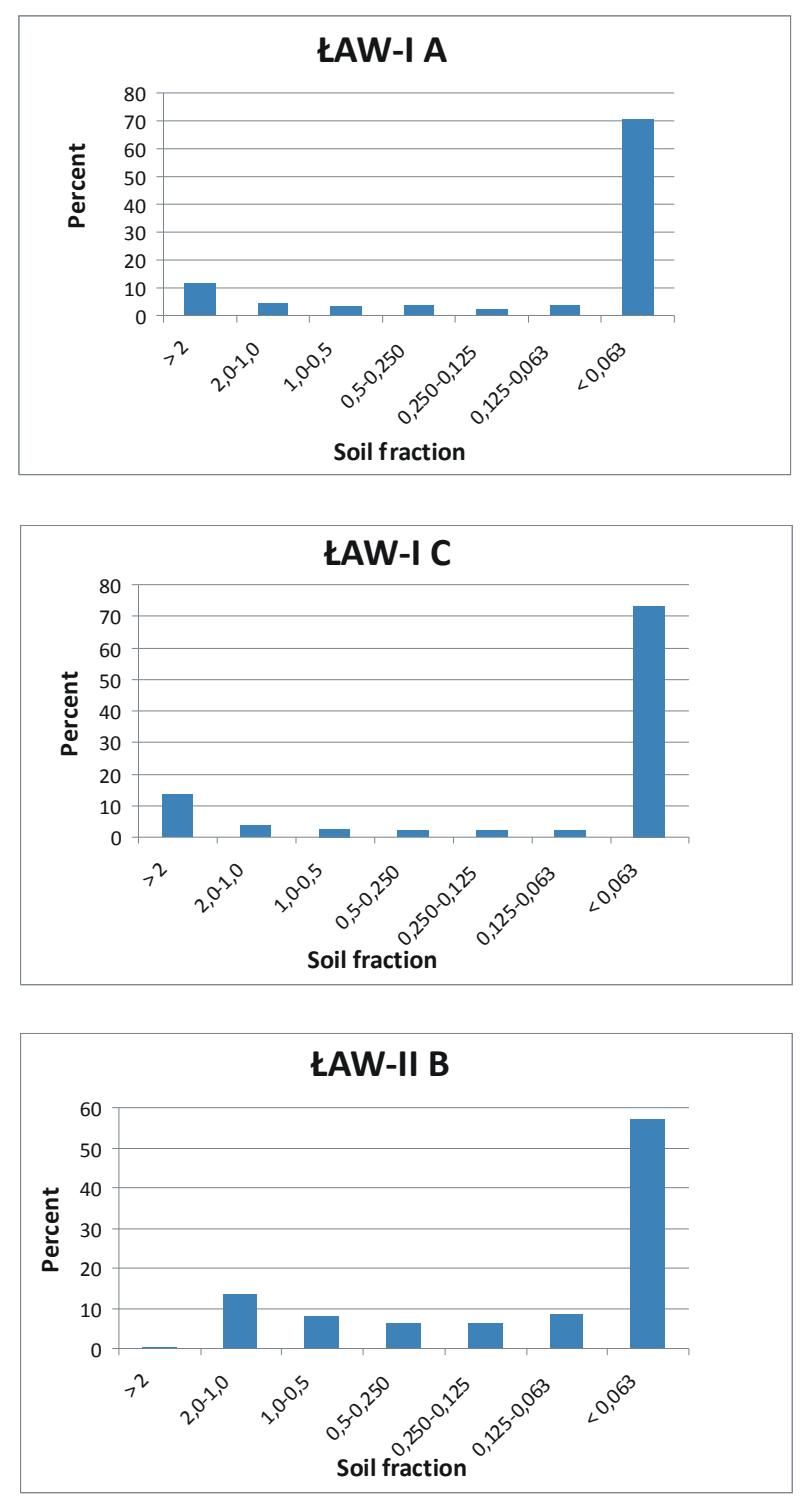

FIGURE 3. Results of grain-size analysis in the examined samples

servations allowed us to determine the primary minerals of the Lawęczna iron deposit, which included minerals from the $\mathrm{FeS}_{2}$ group. These are of a yellow metallic colour with a greenish hue characteristic for marcasite and a metallic gloss that stands out from the surrounding minerals. The XRD analysis revealed goethite ( $4.18 \AA$ basal reflection), which predominates in samples: $\mathrm{LAW}-\mathrm{I}$ A, B and C in sand fraction. In sample $\_A W-I A$ in the same fraction, lepidocrocite was found ( $\sim 6.28 \AA$ basal reflection) beside goethite and this was the only sample in which this mineral was found. XRD analysis did not confirm the presence of hematite, which was distinguished during microscopic observations. Probably this is caused by poor crystallinity of this mineral. Mineralogical composition of sand fraction of samples ŁAW-II A, B and ŁAW-III A is very poor and composed mainly of quartz, whereas
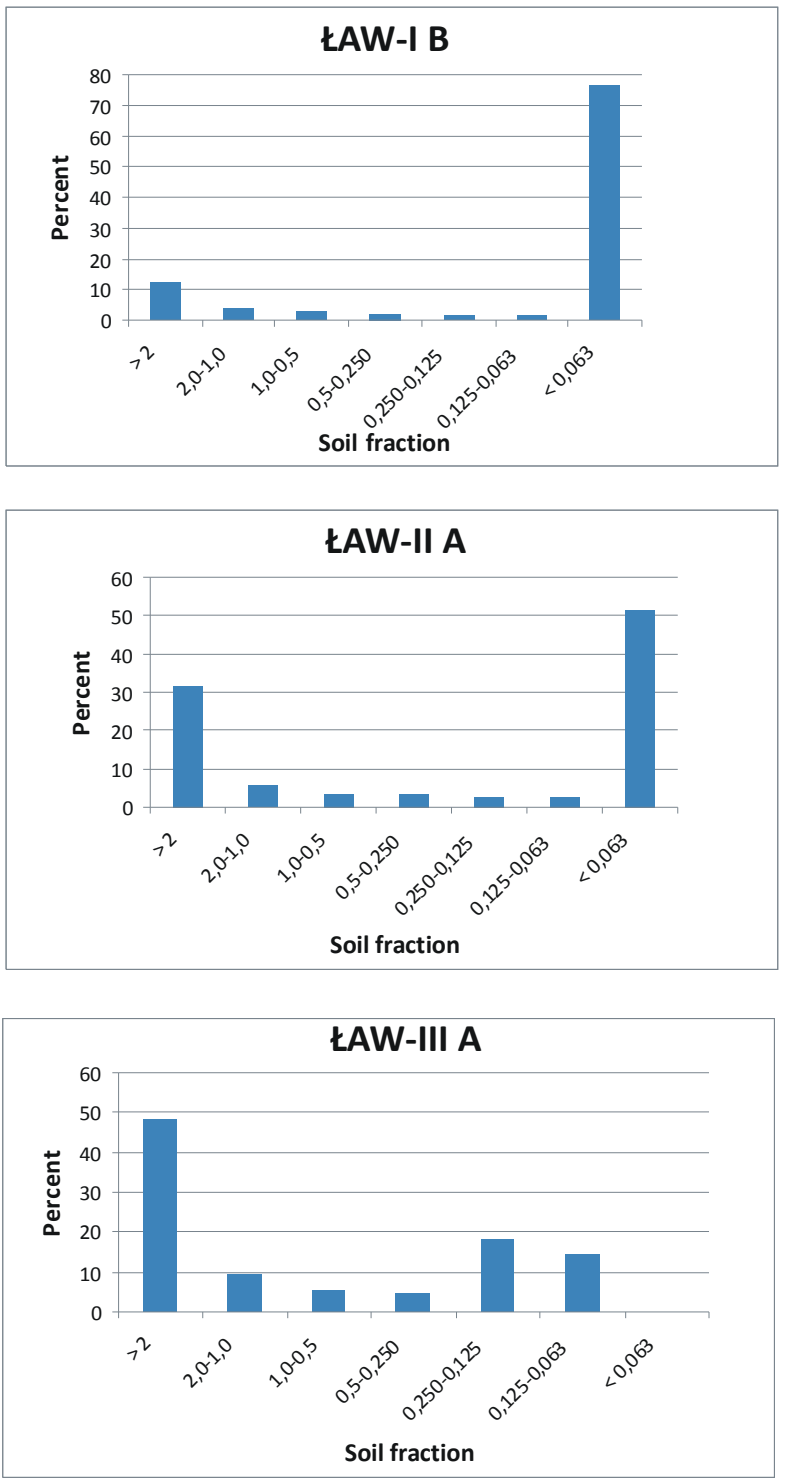

the mineralogical composition of the silt-clay fraction of all samples is very similar and contains mainly quartz $(\sim 3.342 \AA$ basal reflection), kaolinite $(\sim 7.158 \AA$ basal reflection) and probably chlorite (Fig. 4).

\section{Geochemical analyses}

The soil samples were analysed for the content of trace elements: copper, lead, zinc, nickel, titanium and arsenic. Moreover, geochemical characteristics for iron content were measured because historical mining activity focused mainly on iron. The highest content of trace metals was expected in the silt-clay fraction $(<0.063 \mathrm{~mm})$, which shows the highest accumulation capacity for various trace elements, which results from the high sorption 

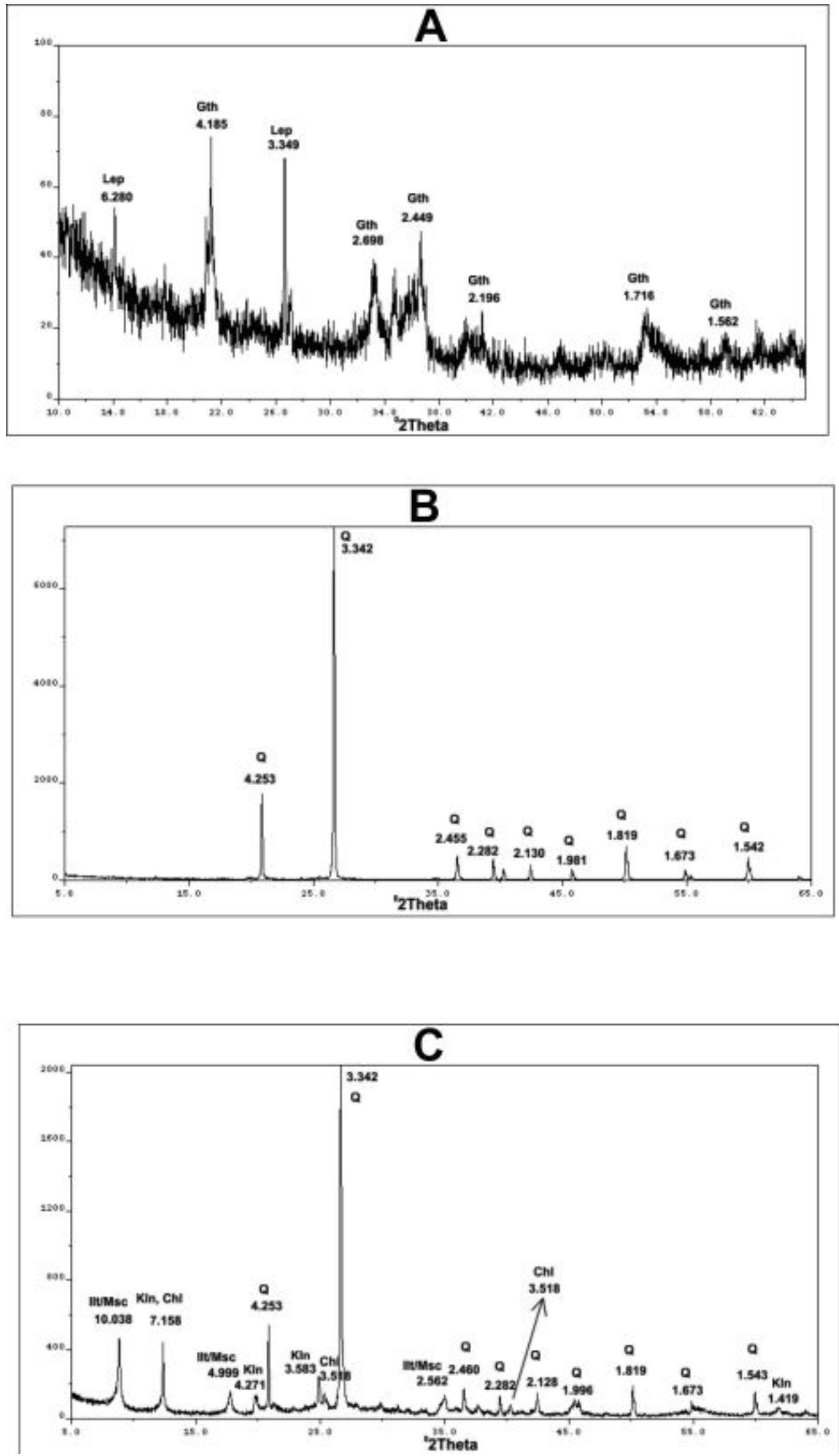

FIGURE 4. XRD patterns of the bulk samples from Ławęczna. Quartz (Q), kaolinite (Kln), addition of chlorite (Chl), illite (IIt) or/ and muscovite (Mus) and lepidocrocite (Lep) was recognized by XRD: A - representative XRD pattern for sand fraction of $Ł A W-I$ A, B and C samples; B - representative XRD pattern for sand fraction of ŁAW-II A, B and ŁAW-III A samples; $\mathrm{C}$ - representative XRD pattern for clay-silt fraction of all samples 
properties of the finest fractions. During the research, attention was also paid to the remaining fraction of the earthy parts, i.e. the sand fraction, which is analysed less frequently during chemical tests. To calculate the level of the soil enrichment in trace elements the enrichment factor (EF) was used (Gałuszka and Migaszewski 2011, Kowalska et al. 2018):

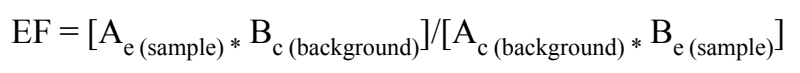

where:

$\mathrm{A}_{\mathrm{e}}-$ element concentration in the environment sample

$\mathrm{B}_{\mathrm{e}}-$ reference element concentration in the environment sample

$A_{c}-$ Clarke value or average shale value of the element

$\mathrm{B}_{\mathrm{c}}-$ Clarke value or average shale value of the reference element

Titanium was treated as a reference element. The results were compared to the geochemical background, which were the average contents of the studied element and the reference element in uncontaminated soils in Poland published by Lis and Pasieczna (1995) in Geochemical Atlas of Poland. The following value ranges are a measure of the degree of soil enrichment in the studied elements:

$\mathrm{EF}<2$ no enrichment or minimal enrichment,

$2 \geq \mathrm{EF}<5$ medium enrichment,

$5 \geq \mathrm{EF}<20$ significant enrichment,

$20 \geq \mathrm{EF} \geq 40$ very high enrichment,

$\mathrm{EF}>40$ extremely high enrichment.

Among the studied elements, the highest enrichment values for both $0.063-2.0 \mathrm{~mm}$ and $<0.063$ fractions were recorded for arsenic, nickel and copper, whereas the lowest values were for zinc and lead (Fig. 5, Table 3). Comparing EF of trace elements in silt-clay fraction with EF of the same elements in sand fraction, the latter stand out with much higher values. In silt-clay fraction the EF for trace elements is much lower than in sand fraction except for arsenic, the concentration of which is a little higher in all samples except for ŁAW-I C. The geochemical characteristics of individual elements in the soils from the Lawęczna mining area are described below.

\section{Arsenic}

The maximum content of this metalloid was 853 $\mathrm{mg} \cdot \mathrm{kg}^{-1}$ in the fraction $<0.063 \mathrm{~mm}$ of the $\mathrm{LAW}-\mathrm{I}$ A sample, whereas the lowest As concentration was $15 \mathrm{mg} \cdot \mathrm{kg}^{1}$ in the $0.063-2.0 \mathrm{~mm}$ fraction of the $\mathrm{LAW}-$ II B sample (Table 2). The average contents of this metal in the analysed soil samples in the fractions $>2.0$, $0.063-2.0$ and $<0.063 \mathrm{~mm}$ were 157, 248 and 518 $\mathrm{mg} \cdot \mathrm{kg}^{-1}$ respectively. The average EF values for the fractions $0.063-2.0$ and $<0.063 \mathrm{~mm}$ were 10 and 9.5 respectively (Fig. 5). These results allow us to classify the investigated soil samples as significantly enriched in arsenic.

\section{Nickel}

This metal is the second abundant of the elements examined in the soil samples. The maximum concentration was $544 \mathrm{mg} \cdot \mathrm{kg}^{-1}$ in the $0.063-2.0 \mathrm{~mm}$ fraction of the $\mathrm{LAW}-\mathrm{I}$ C sample, whereas the lowest $21 \mathrm{mg} \cdot \mathrm{kg}^{-1}$ in the fraction $0.063-2.0 \mathrm{~mm}$ in the samples ŁAW-II B and ŁAW-III A (Table 2). The average contents of this metal in the analysed soil samples in fractions $>2.0,0.063-2.0$ and $<0.063 \mathrm{~mm}$ were 78 , 178 and $94 \mathrm{mg} \cdot \mathrm{kg}^{-1}$ respectively. The average EF values for the fractions $0.063-2.0$ and $<0.063 \mathrm{~mm}$ were 7.5 and 1.6 respectively (Fig. 5). Depending on the fraction analysed, the EF values allow us to classify the tested soils as minimally enriched in nickel for the fraction $<0.063 \mathrm{~mm}$, whereas the sand fraction was significantly enriched in this element.

\section{Copper}

The maximum copper concentration of $318 \mathrm{mg} \cdot \mathrm{kg}^{-1}$ was found in the $0.063-2.0 \mathrm{~mm}$ fraction of the $\mathrm{LAW}-\mathrm{IC}$ sample, whereas the minimum content of $11 \mathrm{mg} \cdot \mathrm{kg}^{-1}$ was in the $0.063-2.0 \mathrm{~mm}$ fraction of the $\mathrm{LAW}-\mathrm{II} \mathrm{B}$ sample (Table 2). The average contents of this metal in the analysed soil samples in the fractions $>2.0$, $0.063-2.0$ and $<0.063 \mathrm{~mm}$ were 117,143 and $92 \mathrm{mg} \cdot \mathrm{kg}^{-1}$ respectively. The average EF values for the fractions $0.063-2.0$ and $<0.063 \mathrm{~mm}$ were 3.3 and 0.88 respectively (Fig. 5). The medium enrichment in copper was found in the sand fraction, whereas the minimal was in the clay-silt fraction. This metal was not found in the $0.063-2.0 \mathrm{~mm}$ fraction of the $\mathrm{LAW}-\mathrm{III}$ A sample (Table 2).

\section{Zinc}

The maximum concentration of zinc was $1041 \mathrm{mg} \cdot \mathrm{kg}^{-1}$ in the $0.063-2.0 \mathrm{~mm}$ fraction of the $\mathrm{EAW}-$ I C sample, whereas the minimum of $10 \mathrm{mg} \cdot \mathrm{kg}^{-1}$ was for the 0.063-2.0 fraction of the $\mathrm{LAW}-\mathrm{II}$ B sample (Table 2). The average contents of this metal in the analysed soil samples in fractions $>2.0,0.063-2.0$ and $<0.063 \mathrm{~mm}$ were 333,348 and $258 \mathrm{mg} \cdot \mathrm{kg}^{-1}$ respectively. The average EF values for the fractions 0.063-2.0 and $<0.063$ were 1.0 and 0.3 respectively (Fig. 5). These values were similar for both fractions and indicted a minimal enrichment in zinc with a slight increase in the zinc content in the sand fraction. 


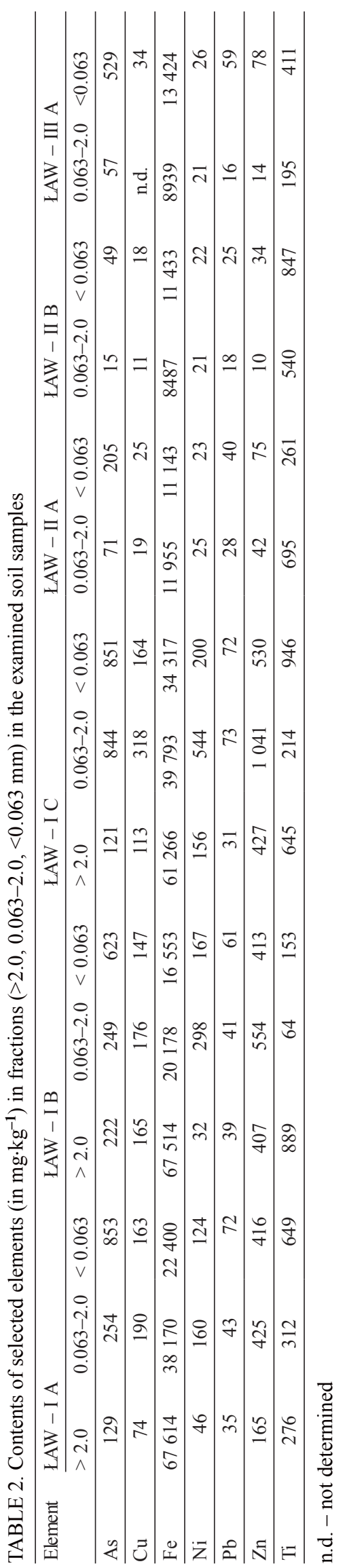

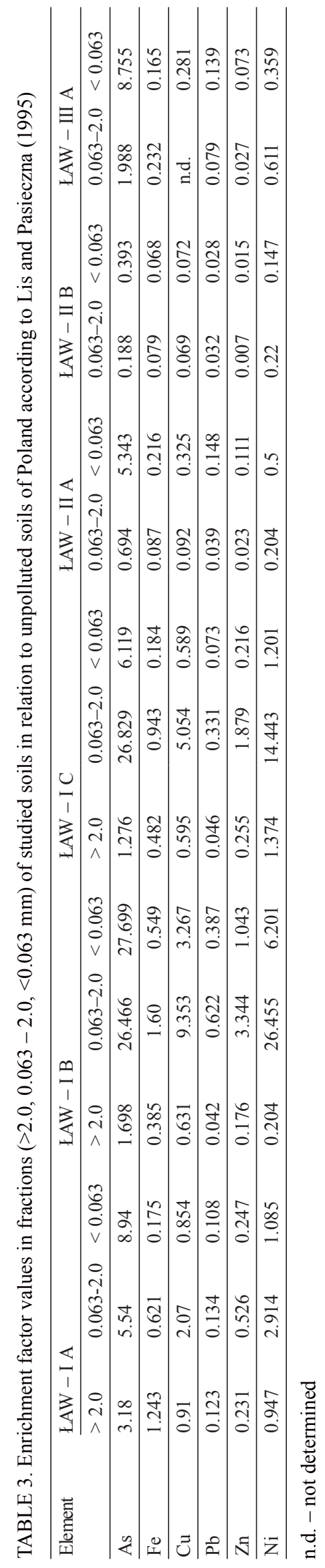

Lead

The maximum content of lead of 72 $\mathrm{mg} \cdot \mathrm{kg}^{-1}$ was found in the $0.063-2.0 \mathrm{~mm}$ fraction of the $\mathrm{LAW}-\mathrm{I} C$ sample, whereas the minimum of $16 \mathrm{mg} / \mathrm{kg}$ was in the $0.063-$ $2.0 \mathrm{~mm}$ fraction of the $\mathrm{LAW}$-III A sample (Table 2). The average contents of this metal in the analysed soil samples in the fractions $>2.0,0.063-2.0$ and $<0.063 \mathrm{~mm}$ were respectively, 35,36 and $55 \mathrm{mg} \cdot \mathrm{kg}^{-1}$. The average EF values for the $0.063-2.0$ and $<0.063$ fractions were 0.21 and $0.15 \mathrm{mg} \cdot \mathrm{kg}^{-1}$ respectively (Fig. 5). These values were minimal and thus, regarding lead content, they classify the studied soils as minimally enriched in this metal.

\section{DISCUSSION}

From the above geochemical soil characteristics, it can be noted that metals such as nickel, copper, zinc and lead were accumulated in the soil fraction of $0.063-$ $2.0 \mathrm{~mm}$, whereas the finest fraction showed a significant enrichment in arsenic. The lowest values of enrichment factors of arsenic and metals were found in the gravel fraction.

The lowest content of metals and arsenic were recorded in the samples, which at the same time have the lowest $\mathrm{pH}$ values (acidic soils), whereas the highest was in the samples with $\mathrm{pH}>7$ (alkaline soils). These observations were consistent with the chemical properties of metals of which migration in supergene environments increases with a decrease in $\mathrm{pH}$ (Kabata-Pendias 2001). Metals in alkaline environments are partially excluded from the geochemical cycle as confirmed by this research. Increased accumulation of metals in the samples from different depths of the first soil core may reflect the mineral composition of the parent rock.

Supergene mineralisation creates incrustations on marcasite, which allows us to determine the initial mineralisation from which the secondary minerals are formed. Soil samples from the second and third boreholes (ŁAW-II and ŁAW-III) are characterized by the domination of quartz and calcite, which results in smaller contents of trace elements in these samples. Increased con- 




FIGURE 5. Mean enrichment factor (EF) for selected elements (As, $\mathrm{Fe}, \mathrm{Cu}, \mathrm{Pb}$. $\mathrm{Zn}$, and $\mathrm{Ni}$ ) in the examined soil samples calculated in relation to unpolluted soils of Poland

centrations of metals and arsenic in the samples from the first sampling site (LAW-I) are associated with undeveloped ore mineralisation and dominance of goethite among the secondary minerals. The latter mineral has higher sorption properties compared with minerals such as quartz or calcite (Krysiak and Karczewska 2008).

The source of the increased concentration of arsenic, which shows the highest enrichment factors among the determined elements, is not necessary associated with the ores of Miedziana Góra. Iron oxides, which are the dominant minerals in Ławęczna, contribute to the increased concentration of this metalloid, which can be supplied from various sources. Interpretation of the soil enrichment level in arsenic indicates the correlation between the high content of this metalloid in the first soil pit (ŁAW-I) and the increased content of iron oxides in the mineral composition. Iron oxides can form a type of a sorption-like geochemical barrier, which is responsible for creating a false geochemical anomaly, considered as a deviation of arsenic concentration from its Clarke value in study area, whereas source of arsenic may not be related to local ore deposit (Skowroński 2007). More justified explanation for the anomalous arsenic content is the increased share of this element in chalcocite $\left(\mathrm{Cu}_{2} \mathrm{~S}\right)$, which was the principal copper ore in the Miedziana Góra deposit (Rubinowski 1971a). In this case, arsenic was inherited from primary minerals of Miedziana Góra deposit. This can be one of the possible explanations for the high concentration of arsenic in sand fraction, which is composed mainly of iron oxides developed from primary minerals of Miedziana Góra deposit.
During chemical weathering arsenic was released from primary ore and partly captured by the finest fraction. This process contributed to the highest concentration of this element in silt-clay fraction.

Global observations indicate that such a high concentration of arsenic in soils is characteristic for hydrothermal ore deposits, especially for copper deposits (Thornton and Farago 1997, Bowell et al. 2014), which suggest that anomalies of this element in study area correlate with Miedziana Góra copper deposit. The source of the anomalous concentration of such trace elements as nickel, copper, zinc and lead is the ore mineralisation (chalcopyrite, galena, pyrite) filling the Miedziana Góra dislocation, on which an iron cap, which was extracted on the Ławęczna Hill, developed as a result of chemical weathering (Urban 1979).

Higher concentration of nickel, copper, zinc and lead in first soil pit ( $\mathrm{AAW}-\mathrm{I}$ ) can also be explained by higher sorption properties of iron oxides, which captured this metals from water draining the primary ore deposit in nearby Miedziana Góra. Although this process can partly clarify the origin of this geochemical anomaly, the authors consider such hypothesis as unjustified due to the lack of any information about geochemical study of waters of Miedziana Góra ore deposit.

Geochemical studies of technogenic soils of Ławęczna iron deposit suggest that this ore is linked with primary copper deposit. The final stage of geochemical and mineralogical studies of the soils formed on iron ore heaps in Ławęczna was a comparison of the average content of the determined elements with 
their average contents in the soils of Kielce and the surrounding area (Fig. 6) (Lenartowicz 1994). This comparison was performed because, according to the authors, an average content of trace elements in the soils of Kielce and surrounding area reflect a more accurate geochemical background, which can be considered as local geochemical background for the study area. Kielce city and its adjacent region were zinc and lead mining areas in the past, which results in higher content of these metals in soils. The results of the comparative analysis confirmed the above-presented geochemical characteristics of the study area soil. The mean concentration of arsenic exceeded local geochemical background of this element. In comparison with the typical metal content in the soils of Kielce and the surrounding area, the soils of Ławęczna are enriched in zinc and nickel. Lead showed the lowest average content among the examined metals, which is close to the average concentration of this metal in soils of Kielce (Fig. 6).

\section{CONCLUSIONS}

1. Geochemical studies of technogenic soils (Technosols) in the region of abandoned iron mine at Ławęczna showed significantly increased enrichment factors of copper, nickel, zinc, lead and arsenic.

2. In comparison with the finest clay-silt fraction, the sand fraction $(2.0-0.063 \mathrm{~mm})$ showed higher concentrations of trace elements. A reverse relation was observed for arsenic, for which higher mean values and enrichment factors were recorded in the finest fraction $(<0.063 \mathrm{~mm})$.

3. Geochemical studies of soils in the areas of historical and present ore mining should not be limited only to the finest fractions, but should include the coarser ones. This occurs because the ore minerals do accumulate in the sand.

4. Elevated concentrations of trace elements in the sand fraction were probably caused by presence of iron oxyhydroxides, which show strong sorption properties and constitute a geochemical barrier. Supergene minerals in soils often inherit the chemical properties of the primary minerals from which they arise, including the enrichment in some

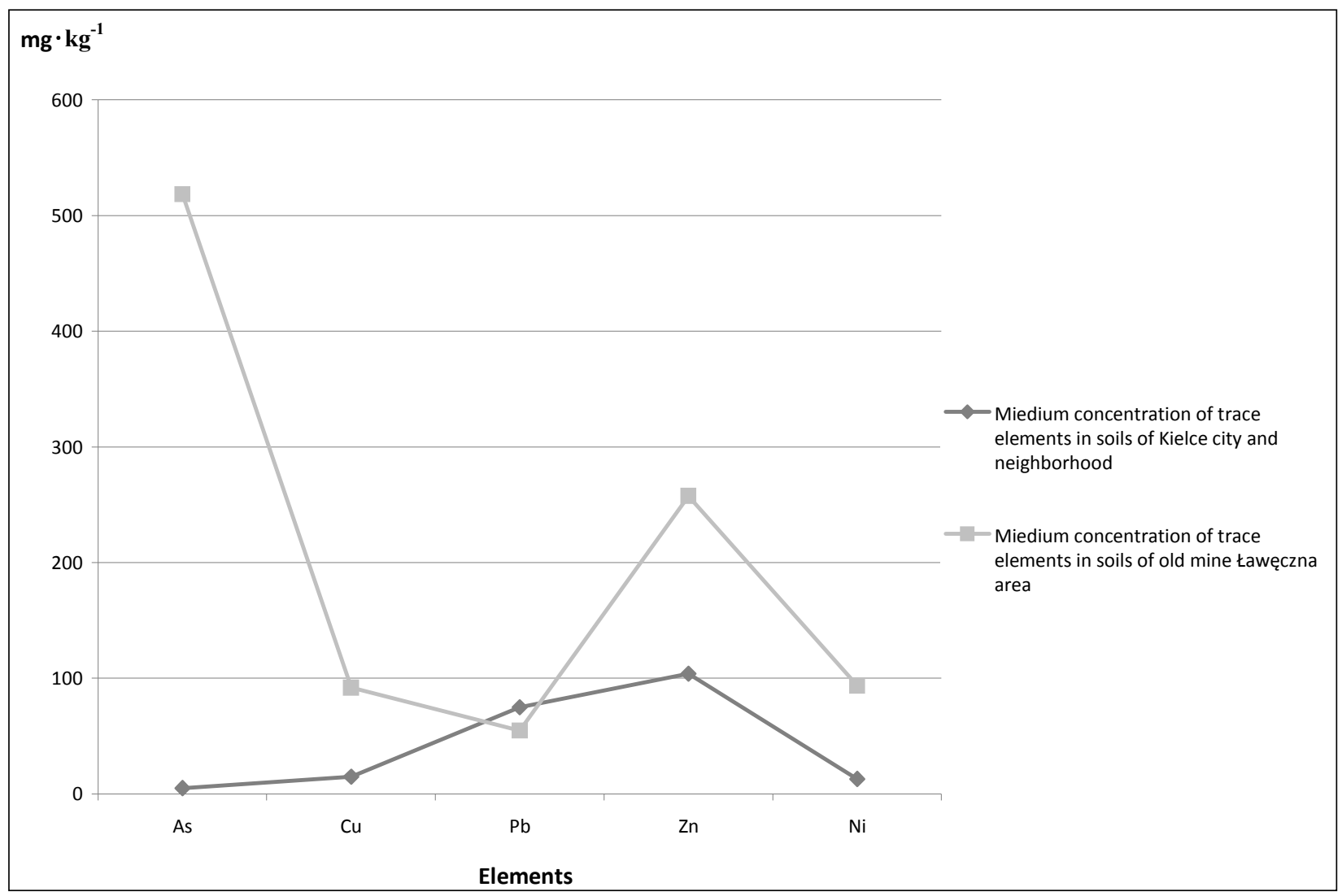

FIGURE 6. Average concentration of trace elements in the examined soils samples with average concentration of these elements in the city of Kielce according to Lenartowicz (1994) 
trace elements. The present studies show the need of conducting mineralogical study simultaneously with geochemical studies.

5. The source of metals in soils from the Lawęczna mining area was the copper deposit occurring in the Miedziana Góra dislocation.

6. High concentration of arsenic in soils is typical for hydrothermal ore deposit, which suggests that there is an anomaly of the old mine Ławęczna iron deposit related with the Miedziana Góra copper deposit.

\section{ACKNOWLEDGMENTS}

The authors acknowledgement of Ms. PhD Agata Duczmal-Czernikiewicz for substantive support and valuable comments. The authors are grateful for reviewers and editorial staff for considerable improvement of the quality of article.

\section{REFERENCES}

Bowell R. et al., 2014. The environmental geochemistry of arsenic - an overview. Reviews in Mineralogy and Geochemistry. 79 (1): 1-7.

Czarnocki J., 1957. Tektonika Gór Świętokrzyskich. Prace Geologiczne PIG XVIII, t. II, z. 3: 23-28.

Gałuszka A., Migaszewski Z.M., 2011. Geochemical background an environmental perspective. Mineralogia 42(1): 10.

Gałuszka A., Migaszewski Z.M., Dołęgowska S., Michalik A., 2018. Geochemical anomalies of trace elements in unremediated soils of Mt. Karczówka, a historic lead mining area in the city of Kielce, Poland. Science of the Total Environment 639: 397-405.

Gałuszka A., Migaszewski Z.M., Dołęgowska S., Michalik A., Duczmal- Czernikiewicz A., 2015. Geochemical background of potentially toxic trace elements in soils of the historic copper mining area: a case study from MiedziankaMt., Holy Cross Mountains, south-central Poland. Environmental Earth Science 74 (6): 4589-4605.

Gałuszka A., Migaszewski Z.M., Duczmal-Czernikiewicz A., Dołegowska S., 2016. Geochemical background of potentially toxic trace elements in reclaimed soils of the abandoned pyriteuranium mine (south-central Poland). International Journal Environmental Science and Technology 13: 2653-2660.

IUSS Working Group WRB, 2015. World reference Base for Soil Resources 2014, update 2015. International soil classification for naming soils and creating legends for soil maps. World Soil Resources Reports No. 106. FAO, Rome.
Kabata-Pendias A., 2001. Trace elements in soils and plants: 33-34. Konon A., 2008. Regionalizacja tektoniczna Polski - Góry Świętokrzyskie i regiony przyległe. Przegląd Geologiczny 56 (10): 921-923.

Konstantynowicz E., 1971. Występowanie złóż rud miedzi i przejawów miedzionośnych w Górach Świętokrzyskich. Monografia przemysłu miedziowego w Polsce, t.1, Wydawnictwo Geologiczne: 231-237.

Kowalska J.B., Mazurek R., Gąsiorek M., Zaleski T., 2018. Pollution indices as useful tools for the comprehensive evaluation of the degree of the soil contamination - a review. Environmental Geochemistry and Health: 10.

Król P., Urban J., 2012. Geologiczne i historyczne dziedzictwo górnictwa miedzianogórskiego. Wydawnictwo JP Kielce: 6-23, 73-97.

Król P., Urban J., 2003. Kopalnie w Miedzianej Górze i w Ławęcznej oraz ochrona ich pozostałości. Rocznik Świętokrzyski Seria B - Nauki Przyrodnicze 29: 4-6, 20-25.

Krysiak A., Karczewska A., 2008. Formy arsenu w zanieczyszczonych glebach rejonu Złotego Stoku w świetle sekwencyjnej ekstrakcji. Roczniki Gleboznawcze - Soil Science Annual 59 (1): 118-127.

Lenartowicz L., 1994. Atlas geochemiczny Kielc. PIG-PIB, Kielce: 5-7.

Lis J., Pasieczna A., 1995. Atlas geochemiczny Polski. PIG, Warszawa.

Rubinowski Z., 1971a. Rudy metali nieżelaznych w Górach Świętokrzyskich i ich pozycja metalogeniczna. Biuletyn Instytutu Geologicznego 247: 46-56.

Rubinowski Z., 1971b. Geologia oraz okruszcowanie miedzianogórskiej strefy dyslokacyjnej. Kwartalnik Geologiczny 15(3): 745-746.

Skowroński A., 2007. Zarys geochemii poszukiwawczej. Wydawnictwo AGH, Kraków: 11-12.

Thornton I., Farago M., 1997. The geochemistry of arsenic. Arsenic. Exposure and health effects: $1-4$.

Urban J., 1979. Mineralizacja strefy utlenionej złoża w Ławęcznie na podstawie materiałów $\mathrm{z}$ hałd. Kwartalnik Geologiczny 23 (2): 507-508.

Uzarowicz Ł., 2011. Technogenic soils developed on mine spoils containing iron sulfides in select abandoned industrial sites: environmental hazards and reclamation possibilities. Polish Journal of Environmental Studies 20(3): 776-780.

Wojciechowski A., 2002. Hałdy dawnego górnictwa świętokrzyskiego jako źródło metali kolorowych i szlachetnych. Przegląd Geologiczny 50(3): 243-244.

Received: March 12, 2018

Accepted: June 4, 2018

Associated editor: L. Uzarowicz 


\section{Geochemia i mineralogia technogenicznych utworów glebowych wykształconych na hałdach dawnego górnictwa rud żelaza na obszarze nieczynnej kopalni Lawęczna (Góry Świętokrzyskie)}

Streszczenie: Artykuł przedstawia wstępne badania geochemiczne i mineralogiczne gleb technogenicznych na obszarze nieczynnej kopalni rud żelaza na wzgórzu Ławęczna koło Miedzianej Góry w Górach Świętokrzyskich. Wyniki analiz chemicznych (XRF) zostały wykorzystane do obliczenia współczynników wzbogacenia (EF) gleb w arsen, nikiel, miedź, ołów i cynk. Otrzymane wartości EF zostały porównane ze średnimi zawartościami badanych pierwiastków śladowych w niezanieczyszczonych glebach Polski, a także w glebach z obszaru Kielc i ich okolic. Najwyższe wartości współczynników wzbogacenia zostały odnotowane dla frakcji piasku $(0,063-2,0 \mathrm{~mm})$ złożonej z tlenowodorotlenków żelaza oraz hematytu, natomiast najniższe wartości EF (Ni 0,22, Cu 0,069, $\mathrm{Zn} 0,007, \mathrm{~Pb} 0,028)$ zostały wyliczone dla frakcji ilasto-pylastej $(<0,063 \mathrm{~mm})$ złożonej głównie z kwarcu i kalcytu. Najwyższy współczynnik wzbogacenia dla As został wyliczony dla frakcji ilasto-pylastej $(27,69)$. Badane próbki gleb charakteryzują się dodatnimi wartościami anomalii pierwiastków śladowych.

Słowa klucze: tło geochemiczne, gleby technogeniczne, hałdy pogórnicze, anomalia geochemiczna 